University for Business and Technology in Kosovo

UBT Knowledge Center

UBT International Conference

2017 UBT International Conference

Oct 28th, 11:00 AM - 12:30 PM

\title{
Corporate Social Responsibility
}

Diamanta Skenderi

University for Business and Technology, diamanta_skenderi@yahoo.com

Besnik Skenderi

University for Business and Technology, besnik.skenderi@ubt-uni.net

Follow this and additional works at: https://knowledgecenter.ubt-uni.net/conference

Part of the Business Commons

\section{Recommended Citation}

Skenderi, Diamanta and Skenderi, Besnik, "Corporate Social Responsibility" (2017). UBT International Conference. 251.

https://knowledgecenter.ubt-uni.net/conference/2017/all-events/251

This Event is brought to you for free and open access by the Publication and Journals at UBT Knowledge Center. It has been accepted for inclusion in UBT International Conference by an authorized administrator of UBT Knowledge Center. For more information, please contact knowledge.center@ubt-uni.net. 


\title{
CORPORATE SOCIAL RESPONSIBILITY
}

\author{
Diamanta Skenderi ${ }^{1}$ and Besnik Skenderi ${ }^{2}$ \\ ${ }^{2}$ UBT - Higher Education Institution, Lagjja KALABRIA p.n., Prishtinë, Kosovë \\ 10000 Prishtina, Kosovo \\ diamanta_skenderi@yahoo.com, besnik.skenderi@ubt-uni.net
}

\begin{abstract}
This paper is about appropriate ethical relations with "stakeholders", considering customers, consumers, owners and employees. In addition, this assignment discuses question do "stakeholders" and "stockholders" have the same moral rights on the corporation and if yes should they have same moral rights. In addition, author had discussed also the proper relationship with employees and conclusion is made based on literature review
\end{abstract}

Keywords: Shareholders, Stakeholders, Social Responsibility

\section{Corporate Social Responsibility}

Corporations are essentially and primarily engine of economic production and distribution (Freeman \& Liedtka , 1991), however as a result of legal changes and consumer increased awareness term corporate social responsibility had appeared as a notion in last century (Frederick, 1994). In addition, according to Kennedy (2006), corporate social responsibility was triggered by the rise of socialism and insufficient attention from spiritual institutions, since "for most of the nineteenth century the hierarchy of the Church paid little attention to economic matters and the idea of corporate social responsibility" (p. 3). Furthermore, corporate social responsibility is considered as a value and it is discussed topic within corporations and within academic literature (Wood, 1991; Carrol, 1979; Davis, 1973). However the challenge remains with corporate social responsibility implementation since leads managers to make decisions about issues beyond their expertise (Freeman \& Liedtka, 1991, p. 94) and the idea of corporate social responsibility has failed to help create the good society.

Reasons for this failure can be attributed to business managers since, according to Carroll, (1991) "social responsibility can only become reality if more managers become moral instead of amoral or immoral" (p. 39), and business moral insight according to Royce, (1865) cited in Goodpaster: "The moral insight is the realization of one's neighbor, in the full sense of the word realization; the resolution to treat him unselfishly" (p. 2).. Since corporates are producing products and service for consumers, and those products are produced by employees and entire business operations are conducted in business environment that is regulated by government, corporates have social responsibility and this responsibility should be part of corporate business planning and budgeting.

\section{Stakeholders and Share Holders Moral Rights}

In current business environment, stockholders are gaining profit through dividend payment (Glac, 2014), and often they are not directly involved in day to day business activities since 
corporations are leaded and managed by hired managers that are protecting stockholders interests (Howton, Howton, \& McWilliams, 2008) and they are paid for their job. However business managers are considered as stakeholders since their benefits are affected by business results of corporation. In addition also consumers, customers and government are categorized are stakeholders since they have their own interest on corporate performance, for example consumers and customers are interested on their right for not to be misinformed (Narveson, 1988), while government is interested to collect taxes (Barber, 2016; Palil, Malek , \& Jaguli, 2016). Furthermore, government as stakeholder is interested to enforce corporations to conduct their business activities within legal system that has to do with consumer health and safety and with environmental protection issues as well.

In addition according to Freeman, (2000) "philosophers see "stakeholders" as a way to bring in the fact that business should be accountable to others while social scientists, on the other hand, see "stakeholders" as a useful unit of analysis that easily depicts the social and societal effects of business" (p. 171). Moreover, stakeholders and shareholders should have moral rights within corporation because they are interrelated with each other, however since stakeholder can be considered also competition, corporates are facing also with negative interested stakeholders.

\section{Relationship of Employees with Stakeholders and Shareholders}

Employees are internal part of corporations and "human beings spend a majority of their waking hours at work" (Freeman, 2000, p. 174). However, when employees are performing their duties, they may find themselves in situation where their personal goals conflict with the company's requirements; and when their ethical principles conflict with them (Narveson, 1988).

In addition, employees are affected by shareholder primacy norm and according to Smith \& Ronnegard (2016) "The shareholder primacy norm is the part of a manager's legal fiduciary duty that requires managers and company directors to make decisions on behalf of the corporation that further the interests of shareholders" (p. 463). The challenge remains when employees are about to implement corporate social responsibility, since shareholder primacy norm may be obstacle and could jeopardize corporate social responsibility. In addition, it will hinder managers from considering the interests of other corporate stakeholders besides shareholders and, employees often are also customers of corporation and there are cases when corporates are issuing stock actions to their employee and there is strong relationship and mutual interests between employees with stakeholders and shareholders

\section{Conclusion}

Corporates and businesses are triggering economic development and social welfare and, corporates are interacting with consumers, customers, employees and with government. In addition, corporates are depending from their customers and as a result of changes in social systems within last century the term corporate social responsibility had appeared. Social corporate responsibility was initiated as a result of social movements around the world, from socialism in the Eastern Europe until civil movements against segregation in USA.

Despite many efforts, the idea of corporate social responsibility has failed to help create the good society because it is depending from moral values of business managers and those values are influenced by shareholder primacy norm. In current business environment, stockholders are business owners and they are controlling business activities through their employees that may be 
appointed as managers and directors and they are considered as stakeholders since they are affected from business results of corporation. Furthermore, stakeholders and shareholders should have moral rights on corporation, since shareholders are investing and they are gaining profit, while stockholders are producing goods and services, they use products and they are influenced by business results of corporations

\section{References}

1. Barber, D. (2016). A theoretical examination of tax evasion among the self-employed. Theoretical \& Applied Economics, 23(1), 119-128.

2. Carrol, A. B. (1979). A three-Dimensional conceptual model of corporate performance. The Academy of Management Review, 4(4), 497-505.

3. Carroll, A. B. (1991). The pyramid of corporate social responslblhty. Business Horizons, 39-48.

4. Davis, K. (1973). The case for and against business assumption of social responsibilities. Arizona State University, 16(3), 312-322.

5. Frederick, W. C. (1994). From CSR1 to CSR2 The maturing of business and society thought. Business and Society, 33(2), 150-164.

6. Freeman, R. E. (2000). Business Ethics at the Millennium. Business Ethics Quarterly, 10(1), 169-180.

7. Freeman, R. E., \& Liedtka , J. (1991). Corporate social responsibility: A critical approach. Business Horizons, 92-98.

8. Glac, K. (2014). The influence of shareholders on corporate social responsibility. Economics, Management \& Financial Markets, 9(3), 34-72.

9. Goodpaster, K. E. (n.d.). Stakeholders and the common good: A polarity within corporate conscience. 1-16.

10. Howton, S. D., Howton, S. W., \& McWilliams, V. B. (2008). The ethical implications of ignoring shareholder directives to remove antitakeover provisions. Business Ethics Quarterly, 18(3), 321-346.

11. Kennedy, R. G. (2006). Corporations, common goods and human persons. Kennedy Final Layout, 4(1), 1-31.

12. Narveson, J. (1988). Ethics in the Business and Professional Life.

13. Palil, R. M., Malek, M. M., \& Jaguli, R. A. (2016). Issues, Challenges and Problems with Tax Evasion: The Institutional Factors Approach. Gadjah Mada International Journal Of Business, 18(2), 187-206.

14. Smith, N., \& Ronnegard, D. (2016). Shareholder primacy, corporate social responsibility, and the role of business schools . Journal of Business Ethics, 134(3), 463-478.

15. Wood, D. J. (1991). Toward improving corporate social performance. Business Horizons, 66-73. 